\title{
The Revival of Guoxue
}

Historical Antecedents and Contemporary Aspirations

\section{John Makeham}

\section{(2) OpenEdition}

\section{Journals}

Electronic version

URL: http://journals.openedition.org/chinaperspectives/5372

DOI: $10.4000 /$ chinaperspectives.5372

ISSN: 1996-4617

\section{Publisher}

Centre d'étude français sur la Chine contemporaine

\section{Printed version}

Date of publication: 1 January 2011

Number of pages: 14-21

ISSN: 2070-3449

\section{Electronic reference}

John Makeham, «The Revival of Guoxue », China Perspectives [Online], 2011/1 | 2011, Online since 30 March 2014, connection on 28 October 2019. URL : http://journals.openedition.org/chinaperspectives/ 5372 ; DOI : 10.4000/chinaperspectives. 5372 


\title{
The Revival of Guoxue
}

\author{
Historical Antecedents and Contemporary Aspirations
}

\author{
IOHN MAKEHAM*
}

\begin{abstract}
After some opening remarks on the recent commodification of guoxue, I first trace the rise of guoxue in the contemporary period, and then I examine two topics in more detail: guoxue's historical and contemporary transformation into an academic discipline; and the immediate origins of guoxue's pronounced ethnoepistemological character. Through this examination my aim is to bring into greater relief some of the aspirations invested in guoxue by its contemporary protagonists, and also to highlight some of the conundrums associated with those aspirations.
\end{abstract}

KEYWORDS : Guoxue, academic discipline, ruxue, ethnoepistemology, Chinese philosophy, cultural identity

$$
\int
$$

ust as the discourse on culture in 1980s China was dubbed by some commentators as "culture fever" (wenhuare) and the rise of ruxue in the 1990s was referred to as "ruxue fever," so too the strong interest in guoxue over the past five or so years has been characterised as "guoxue fever." (1) Although much of the discourse on guoxue over the past decade has been produced and consumed by academics, one of the more distinctive aspects of the development of guoxue over this period has been its appeal to a much broader cross-section of literate China (an achievement greatly facilitated by the involvement of the media and the market). Thus, in addition to the establishment of guoxue colleges (guoxueyuan) and guoxue research centres (guoxue yanjiuyuan/yanjiusuo) at prestigious universities, there are also numerous publications (including guoxue almanacs), websites, blogs, study groups, televised lecture series, summer camps, short-term courses, whole sections of bookstores, and supplements in newspapers devoted to guoxue. Even guoxue academic celebrities such as Yi Zhongtian (易中天), Yu Dan (于丹), and the like have been created. The China Central Television (CCTV) televised lecture series Lecture Room (百家講壇, baijia jiangtan) was instrumental in providing a host of lecturers, including $Y i$ and $Y u$, with a national profile after it changed its format to focus on cultural and historical topics in 2004. ${ }^{(2)}$

No doubt, the commodification of guoxue partially explains its recent popularity. For example, in May last year, it was reported that the popular website Guoxuewang (3) - online for a little over a decade now - had already exceeded an impressive 500,000 daily hits. (4) This site was purchased by a producer of digital editions of traditional Chinese texts, Beijing Guoxue Times Culture Co., Ltd. (Beijing guoxue shidai wenhua chuanbo gufen youxian gongsi), after its establishment in 2002. On 29 May 2009, the company was listed on the Shenzhen stock exchange, the first "guoxue" enterprise to do so.

The example of "guoxue spice girl" (國學辣妹, guoxue lamei), who came to brief notoriety in 2006, testifies just how pliant (and crass) the guoxue brand can be when commodified. As reported in danwei.com:

The movement to revitalize traditional learning is well on its way to success now that it has a pin-up girl. Bai Luming, a 19-year-old student at the National Academy of Chinese Theatre Arts, claims to be

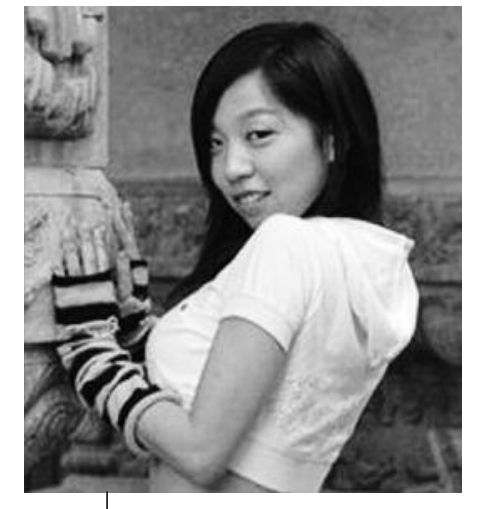

The "Guoxue Spice Girl" (c) (Source: http://www.danwei.org/ images/JDM061108guxuebabe2.jpg) a 53rd-generation descendant of the poet Bai Juyi...."My greatest talent is seduction, and not even Confucius is out of the question. Confucius said 'Appetite for food and sex is human nature.' "...."Guoxue Spice Girl," as she is known, posts samples of her poetry to demonstrate her commitment to guoxue, as well as photos of herself imitating Britney Spears to demonstrate her commitment to seduction. ${ }^{(5)}$

The following frank comments by Wu Genyou (皿根友) provide an unusually revealing "insider's" perspective into the perceived connection between guoxue and the market economy:

John Makeham is Head of the Chinese Studies Department, School of Culture, History and Language, at The Australian National University. He is a specialist in Chinese intellectual history with a particular interest in Confucian philosophy. He recently completed an edited volume on Neo-Confucian philosophy and an edited volume on the formation of Chinese philosophy as an academic discipline. He is currently preparing an annotated translation of Xiong Shili's Xin Weishi lun (New Treatise on Cognition-only), a seminal text in twentieth-century Chinese Buddhist and Confucian philosophy.

1. As with ruxue, guoxue is a complex term which takes on different senses in different historical periods.

2. In reflecting on the general interest in history and historical topics in contemporary China, Michael Szonyi notes that televised miniseries such as Lecture Room "have all been multi-media phenomena, taking shape in books, on the Internet, on electronic bulletin boards and sometimes also as computer games, and on television in the form of televised lectures and historical miniseries." Referring to the recent work of Matthias Niedenführ, he further notes that "television miniseries or historical soap operas have effectively created nationwide events by virtue of their simultaneous daily broadcasts. These events encourage the citizenry to reflect on and talk about national history." Michael Szonyi, "Ming Fever: The Present's Past as the People's Republic Turns Sixty," China Heritage Quarterly, no. 21, March 2010; Matthias Niedenführ, "Historical Revisions and Reconstructions in History Soaps in China and Japan," in Contested Views of a Common Past: Revisions of History in Contemporary East Asia, edited by Steffi Richter, Chicago, University of Chicago Press, 2008.

3. http://www.guoxue.com.

4. "First listing of guoxue shares on the Shenzhen Stock Exchange" (Shou zhi "guoxue gu" zai Shen jiaosuo guapai shangshi), Guangming ribao, 4 May 2009

5. See Joel Martinsen, "Guoxue and online exhibitionism," 8 November 2006, http://www.danwei.org/ internet/exhibitionism_for_confucius.php. See also the Li Qian, "Narcissism produces cyber celebrities," 22 November 2006, http://www.chinadaily. com.cn/china/2006-11/22/content_740238.htm. 
The area of the market economy in which guoxue has a direct role is the culture industry. Basically, the culture industry is a kind of "content industry" or "creative industry." Guoxue can provide "content" for the culture industry, including a large quantity of cultural symbols (such as pictographic characters, dragons, red lanterns, and so forth) as well as cultural material (such as classical texts, historical persons, story plots, and so forth). Having undergone an appropriate process of creative conversion they then become renewable resources of cultural capital....For marketing, guoxue can also contribute useful sales strategies. For example, many businessmen who have used the thinking found in Sunzi's Art of War or Romance of the Three Kingdoms to draw up sales strategies have achieved phenomenal results.... It has always been the case that the question of just how much room for development there is in the relationship between guoxue and the market economy is determined by just how active guoxue itself is. As Marx said, "The extent to which theory is realised within a country is determined by the extent to which theory meets the needs of that country." Borrowing this expression, we might say that the degree of intimacy between guoxue and the market economy is determined by the degree to which guoxue meets the needs of the market economy. In regard to this, we maintain a positive and optimistic attitude. ${ }^{(6)}$

These comments are especially intriguing given that $\mathrm{Wu}$ is not only a prominent scholar in the field of Confucian philosophy but also Deputy Director of Wuhan University's Guoxue Institute (more on this institution below).

There is, however, more to guoxue than just its recent commodification. In what follows, I first trace the rise of guoxue in the contemporary period, and then examine two topics in more detail: guoxue's historical and contemporary transformation into an academic discipline; and the immediate origins of guoxue's pronounced ethnoepistemological character. It is hoped that this examination will help bring into greater relief some of the aspirations invested in guoxue by its contemporary protagonists, as well as highlighting some of the conundrums associated with those aspirations.

\section{The rise of guoxue in the contemporary period}

The rise of guoxue over the past decade has historical roots stretching back more than a century. In the contemporary period, we might note the establishment already in 1984 of the Academy of Chinese Culture (中國文 化書院, Zhongguo wenhua shuyuan) with Tang Yijie (湯一介) serving as director and boasting such prominent members as Feng Youlan (馮友蘭), Zhang Dainian (張岱年), Liang Shuming (梁漱溟), Ji Xianlin (季羡林), and Zhu Bokun (朱伯昆). Between 1985 and 1999, the Academy held a large number of lectures, classes, and correspondence courses on aspects of traditional Chinese culture and comparative studies of Chinese and Western culture.

It was, however, a series of events that marked the rise of guoxue in the early 1990s. First was the establishment of the Research Centre for Traditional Chinese Culture at Peking University in early 1992, followed by the publication of the journal Guoxue yanjiu (國學研究, Research on Guoxue) in May 1993. A full-page article in Renmin ribao on August 16, 1993, introduced the rise of guoxue at Peking University. This was the first major ar- ticle in a supplement of that paper to report on events at the university since 1989. Two days later, another article, on the front page of Renmin ribao, praised the guoxue research being promoted at the university. In October 1993, Peking University student groups organised a "Guoxue Month" with lectures and talks from prominent figures such as Ji Xianlin, Deng Guangming (鄧廣銘), and Zhang Dainian. In November, CCTV reported on the guoxue fever. In December, Peking University and CCTV agreed to produce a 150-part televised documentary on traditional Chinese culture. The agreement stated: "This production will be guided by Marxism, fully implement the principles of 'critical inheritance' and 'making the past serve the present,' and will pay attention to social benefit.... The aim is to promote the excellent traditional culture of the Chinese nation so as to boost the people's self-confidence, self-respect, and patriotic thought." (7)

Guoxue achieved greater national prominence in 1994 with the appearance of an article in the June issue of Zhexue yanjiu by Li Denggui (李登貴) (under his pen name Luo Bu), an assistant editor in the Philosophy Institute of the Chinese Academy of Social Sciences. This piece was directed at an article in the previous issue by Chen Guogian (Peking University environmental scientist), in which Chen argued that traditional Chinese dialectic ${ }^{(8)}$ treated subject and object as constituting a unity. According to Chen, in the prevailing form of dialectic in the West and in Marxism, subject and object are in opposition to one another. Thus, whereas in traditional Chinese dialectic the relationship is one of harmony, in the West and in Marxism the relationship is one of conflict and struggle. Li saw this as symptomatic of a more general tendency being promoted by the guoxue camp to banish the "new culture of socialism" from the fold of Chinese culture. He was also critical of those he characterised as attempting to construct a new theoretical system based on the teachings of Confucius and Dong Zhongshu to rival Marxism. ${ }^{\left({ }^{9}\right)}$ From this point on, both the rise of guoxue and "ruxue fever" became the focal point of critical debate, the two phenomena being conflated.

Debates about guoxue were ideologically charged because of the fear in some quarters that ruxue and guoxue represented a threat to Marxist orthodoxy and to socialism in China. According to Zheng Jiadong:

After 1989, although the liberal camp suffered a setback, research on, and the promotion of, traditional culture were unaffected. On the contrary, due to the encouragement received from the authorities and from the international arena, research on traditional culture prospered and gradually became an influence, ambience, and force. At that point, some people explicitly raised the issue of "a subtle connection" between "the fad of returning to the cultural past" and "the declining interest in Marxism." They also pointed out that they "did not rule out the possibility that some people were plotting to use the suspect concept of 'guoxue' to achieve their goal of renouncing socialism's new culture as alien to Chinese culture."(10)

6. "Guoxue and the Market Economy" (Guoxue yu shichang jingji), Guangming ribao, 1 September 2009

7. "Views on the question of traditional culture" (Chuantong wenhua wenti bitan), Kongzi yanjiu, no. 2, 1995 , p. 5.

8. Chen Guogian (陳國謙), "Philosophical reflections on environmental problems" (Guanyu huanjing wenti de zhexue sikao), Zhexue yanjiu, no. 5, 1994, pp. 32-37.

9. Luo Bu (羅卜), "Guoxue, turning back the clock, culture: Evaluating an ideological trend deserving of attention" (Guocui, fugu, wenhua: ping yizhong zhide zhuyi de sixiang qingxiang), Zhexue yanjiu, no. 6, 1994, p. 36.

10. Zheng Jiadong, "New Confucianism's new lease on life" (Dang dai xin ruxue de xin shiming), Ehu yuekan, no. 246, 1995, p. 19. 
In January 1995, the China Confucius Foundation organised a symposium to discuss the relationship between the guoxue fad and Marxism. A counteroffensive directed at critics of guoxue was launched in 1995, in the second issue of Kongzi yanjiu. The common theme of this group of articles was not only that guoxue was compatible with Marxism but that China's traditional culture was an important aspect of socialism with Chinese characteristics and needed to be studied and properly evaluated. The relationship between guoxue and Marxism continued to be the focus of the debate throughout 1995.

By 1997, a sort of compromise strategy emerged: guoxue was concerned not narrowly with the rujia tradition but with the whole range of traditional scholarly culture. Fan Guiping (范桂萍) and Gan Chunsong (干春松) (at the time both employed at the Chinese Academy of Social Sciences), for example, argued that guoxue reflected a growing affirmation of "the national culture" and was an expression of pluralism. The authors commented: "It is thus apparent that the purpose of guoxue is to promote the complete incorporation of the cream of Chinese culture within the context of global culture. There is a clear difference in intellectual orientation between this and the strong 'protecting the way' mentality of nationalessence ideology and New Confucianism." For the authors, the Post-New Confucian Age (which they trace to the rise of guoxue) was a development that signalled the rejection of New Confucian moral idealism, as Chinese intellectuals adopted a new inclusive attitude toward China's cultural heritage: "That is, when people affirm the contemporary value of China's cultural tradition, they are already beginning to transcend blatant sectarian biases, and_-against the backdrop of world culture-are emphasising the comprehensive assimilation of all forms of traditional wisdom: rujia, daojia, Mohist, and all the various schools of philosophers." (11)

In the 1990s, guoxue was foremost a political concept in which the guo of guoxue rather than the xue of guoxue was the real focus. Those aligned with the ruxue revivalist movement sought to champion a cultural nationalism based on the claim that rujia cultural values were at the core of Chinese national identity. Those aligned with the state saw this as a challenge to their own claim over the nation-state.

Since the late 1990s, the issue of how to define and demarcate guoxue has increasingly become a regular topic of discussion. Contemporary definitions of guoxue vary, often considerably, but a majority of scholars clearly favour a broad definition, usually along the lines of: "a synonym for all of China's past learning"; "a general collective term for traditional Chinese culture"; or "research on Chinese culture." A related feature of this more recent discourse has been a preponderant concern with developments in guoxue during the first three decades of the twentieth century. Many scholars seem to regard this period as providing the appropriate benchmark for how to define the scope and character of guoxue.

\section{The transformation of guoxue into an academic discipline}

Most recently, Chen Lai (Director of the Guoxue Research Institute, Tsinghua University) has discerned three broad periods of guoxue in the first three decades of the twentieth century. The first period was the first decade of the twentieth century, and during this period he characterises guoxue as essentially a political concept. The second period was from about 1911 to the early 1920s, when guoxue was used as a cultural concept. And in the third period, post-1920, he finds that guoxue increasingly came to be used as an academic concept, as reflected in the number of academic institutions that established guoxue research institutions during this period in the wake of the "putting national heritage in order" (整理國故, zhengli guogu) movement. According to Chen, it was also in this period that the concept came to mean a research system or scholarly system, specifically a field of learning concerned with research on China's past historical culture. ${ }^{(12)}$

This division prompts several observations. First, the claim that guoxue was transformed from a political concept in the first period into an academic concept in the third period is consistent with the "nativist" and "cosmopolitan" distinction made by Cheng Gang and Cao Li as referred to by Arif Dirlik in his introductory chapter to this issue of China Perspectives. Ironically, the nativist mode that dominated the first phase of China's embrace of guoxue had its roots in Japan. As is now well known, the modern term guoxue is adapted from the Japanese term kogukagu (國學), which in turn originally referred to a scholarly movement that developed in the eighteenth century ${ }^{(13)}$ as a rejection of so-called Kangaku (漢學, Han Learning) associated with canonical Chinese texts, championing instead a return to early Japanese works that, it was asserted, had escaped Chinese influence, such as Kojiki (古事記), Nihon shoki (日本書紀) and Manyöshü (萬葉集). "From the 1880s onward, scholars working within the new modern disciplines of 'National Literature' and 'National History' argued that Kokugaku represented the rise of a modern sense of nation among the Japanese people." (14) When Chinese intellectuals such as Liang Qichao (梁啟超, 18731929) introduced the concept of guoxue into China in the early years of the twentieth century, one of their key motivations was to nurture national citizens by protecting the "national essence" guocui (國粹), a concept derived from scholars such as Shiga Shigetaka (志賀重昂,1863-1927), active in the 1880s, and whose kokusui shugi (國粹主義) movement advocated preservation of Japan's cultural identity even as it modernised. Sang Bing (桑兵) (Zhongshan University) maintains that in the early years of the last century, guoxue was the product of a concern that Chinese learning would be washed away in the tide of Western learning. This led not only to the notion of guoxue but also to National Painting, National Theatre, National Language, National Medicine, National Martial Arts, National Dress, and so forth. ${ }^{(15)}$

One intriguing aspect of the nativist orientation in this early phase of guoxue is its criticism of ruxue, a position that contrasts sharply with the current guoxue movement's privileging of learning and texts associated with ruxue. Already in 1902, Liang Qichao had proposed the idea of launching a dedicated newspaper on guoxue to be called Guoxue bao, although it took another four years for the proposal to be re-

11. Fan Guiping and Gan Chunsong, "The post-New Confucian age: Concerning the evaluation of a change in direction in studies of traditional culture (Hou xin rujia shidai: guanyu chuantong wenhua yanjiu zhuanxiang de pingjie), Zhexue dongtai, no. 3, 1997, pp. 25-26.

12. Chen Lai, "The path of new guoxue" (Xin guoxue zhi lu), Guangming ribao, 26 October 2009. This division also seems to correspond with Chen's claim that guoxue has three broad senses: China's traditional scholarly culture before the introduction of Western learning; a general reference to traditional Chinese culture; and the system of research produced by the modern study of traditional scholarship and traditional culture. Chen Lai, "How should guoxue fever be regarded?" (Ruhe kandai guoxuere), Guangming ribao, 2 August 2010.

13. Some scholars trace its origins to the previous century.

14. Susan Burns, "The Kokugaku (Native Studies) School," Stanford Encyclopedia of Philosophy, http://plato. stanford.edu/entries/kokugaku-school/, accessed 1 June 2010. Burns further notes, "After World War II, however, Kokugaku came to be widely viewed as the intellectual point of origin for views that contributed to the rise of fascism and militarism in Japan in the 1930s and 40s."

15. See Sang Bing, The history of guoxue (Guoxue de lishi), Beijing, Guojia tushuguan chubanshe, 2010, pp. $1-2$. 
alised. ${ }^{(16)}$ A key motivation behind Liang's proposal was to foster an environment conducive to the free expression of thought. In an essay published in 1902, "Preserving Rujiao is Not the Way to Respect Confucius," he blamed the demise of scholarly learning since Han times on rujiao, in which Confucius was regarded as a religious leader rather than as a philosopher. (In making these claims he was directly challenging the views of his former teacher and mentor, Kang Youwei [康有為,18581927].) (17) Liang instead held up the Warring States period as a model of intellectual vibrancy and freedom.

A related development in the unfolding guoxue movement of this period was the inordinate focus on the pre-Qin masters. ${ }^{(18)}$ A key work promoting Masters Studies was Zhang Binglin's (章炳麟, aka Zhang Taiyan 章太炎,1869-1936) Qiushu (信書, Writings to Prompt Action; 1900). Qiushu broke the traditional mould in which ruxue was accorded an elevated status, by treating the ru (儒) as just one school among many. In the "Xue bian" (學變, Transformations in Learning) chapter, Zhang praised Wang Chong (王充, 27-ca. 100) for his criticisms of Confucius. In the "Ding Kong" (訂孔, Evaluating Confucius) chapter, he described how the teachings of Confucius and the ru were based on those of Laozi, and presented Confucius as a mere scribe enjoying an undeserved reputation, and as inconsistent in his doctrines. He also portrayed both Mencius and Xunzi as superior to Confucius. Indeed, already in 1897 Zhang had published "Hou sheng" (後聖, Later Sage), in which he placed Xunzi on an equal footing with Confucius and claimed that for more than 2,000 years the meaning of Xunzi's essays such as "Zheng ming" (正名, On the Correct Use of Names) and "Li lun" (禮論, Discourse on Ritual) had not been properly understood. (19) There were, of course, nationalistic (and hence anti-Manchu) factors involved in this connection between the guoxue movement and the pre-Qin or late Zhou masters, as Arif Dirlik has pointed out in his essay in this issue of the journal.

As for guoxue in its "cosmopolitan" mode, Dirlik remarks that it was "enunciated most explicitly by Hu Shi, who sought to establish guoxue as the critical study of the national past through the investigative technologies of Euromodernity; guoxue is understood in this case as national studies, informed by modern methods, with the past as its object." One of the curious factors in the contemporary academic articulation of guoxue is the co-existence of nativist and cosmopolitan elements. Thus in an essay outlining the mission of Tsinghua University's recently revived Tsinghua University Guoxue Research Institute, Director Chen Lai writes:

Today's Tsinghua University Guoxue Research Institute continues with the old Tsinghua University Guoxue Research Institute's understanding and employment of the concept "guoxue"; we also intend to adopt "Chinese subjectivity, world vision" as our goal in inheriting and carrying forward the scholarly spirit of the old Guoxue Research Institute. "Guoxue research" requires that as Chinese scholars conduct research on their own history and culture they give prominence to the subjectivity of Chinese culture; give full play to the strengths of Chinese scholars' researching their own culture; and highlight the historical understanding, problematic, and culture spirit of Chinese scholars. Giving prominence to this type of cultural subjectivity does not mean shutting oneself off from external discourse; rather, it means establishing one's own position among world cultures and in the framework of close liaison with international research on Chinese culture. We hope that in this context,

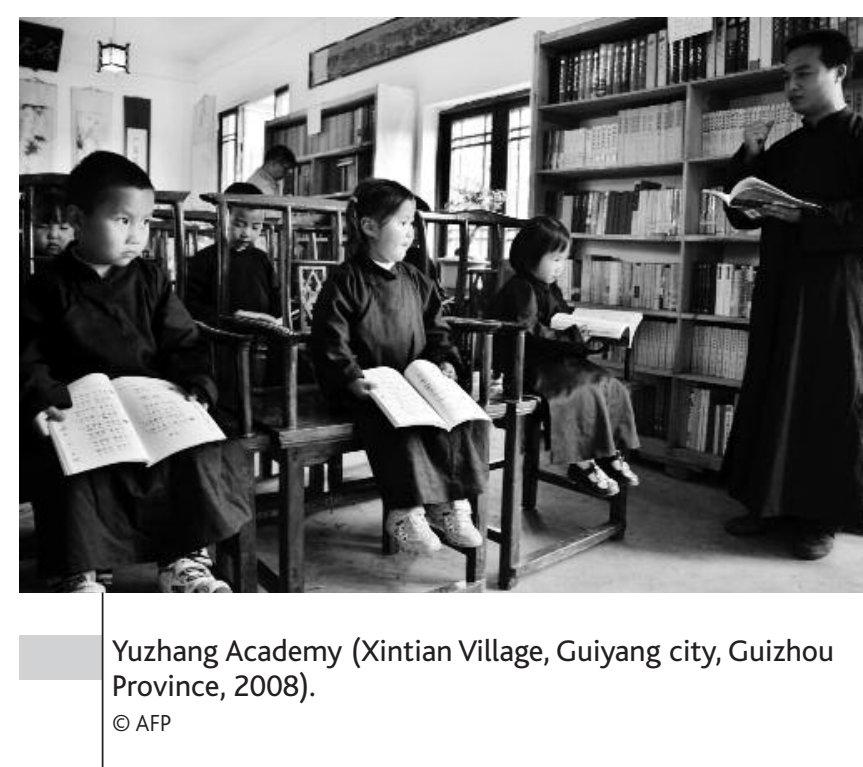

Chinese people will not simply be novices in the realm of international scholarship on Chinese culture. Becoming more than mere novices will enable us to become the mainstream in the future. (20)

As might be expected, the nativist and the cosmopolitan have not always been easy bedfellows in recent scholarship, as is well evidenced by the paradigm shift referred to as moving from "doubting antiquity" (疑古, yigu) to "explaining antiquity" (釋古, shigu) (21) as attempts were made over the past two decades to reconstruct and re-affirm facets of early ru intellectual history based on the interpretation of recent archaeologically recovered texts, particularly issues of authorship and transmission lineages, at the expense of scholarly rigor. The "doubting antiquity" movement is generally traced to Gu Jiegang (顧頴剛), who in 1926 argued that in many writings from Warring States period through to the Han, the later a mythical emperor appeared in a text, the earlier the claim was made for when that figure lived. (22) Exceptionally prominent supporters of the current guoxue revival (who are also exceptionally prominent supporters of the ongoing

16. The Society for the Preservation of National Learning (Guoxue baocunhui; 1905) published Guocui xuebao between 1905 and 1912.

17. Liang Qichao, "Bao jiao fei suo yi zun Kong lun," in Ge Maochun and Jiang Jun (eds.), Selected essays on Liang Qichao's philosophical thought (Liang Qichao zhexue sixiang lunwen), Beijing, Beijing daxue chubanshe, 1984, pp. 95-103.

18. John Makeham, "The Role of Masters Studies in the Early Formation of Chinese Philosophy as an Academic Discipline," in John Makeham (ed.), Learning to Emulate the Wise: The Genesis of Chinese Philosophy as an Academic Discipline in Twentieth-Century China, Hong Kong, Chinese University Press, 2011.

19. As contemporary scholar Wang Fansen (王沉森) points out, this essay was written in response to an anti-Xunzi movement in the late Qing initiated by a young Liang Qichao (1873-1929) (who at the time still aligned himself with New Text scholarship), Tan Sitong (譚嗣同, 1865-1898), and other New Text partisans. Wang Fansen, Zhang Taiyan's thought and its assault on the ruxue tradition (Zhang Taiyan de sixiang ji qi dui ruxue chuantong de chongji), Taipei, Shibao wenhua chuban youxian gongsi, 1985, p. 31. See also Liang Qichao, Overview of Qing learning (Qing dai xueshu gailun), Taipei, Taiwan shangwu yinshuguan, 1993/1921, pp. 138-139.

20. Chen Lai, "The mission of the Tsinghua Guoxue Research Institute" (Qinghua Guoxue yuan de shiming), http://www.tacl.tsinghua.edu.cn/publish/gxyjy/93/index.html, accessed 5 September 2010.

21. This reorientation was highlighted with the publication of Li Xueqin (李學勤), Stepping out of the age of doubting antiquity (Zouchu yigu shidai), Shenyang, Liaoning daxue chubanshe, 1994. (His essay of the same title was published in Zhongguo wenhua, no. 9, 1992).

22. Although $\mathrm{Gu}$ used the term yigu to refer to his own historical attitude, it was perhaps a decade later that the distinction between yigu, xingu (信古, believing antiquity), and shigu (explaining antiquity) started to be employed. For details see John Makeham, Lost Soul: "Confucianism" in Contemporary Chinese Academic Discourse, Cambridge, MA., Harvard University Asia Center, 2008, p. 210, fn. 6; Arif Dirlik, Revolution and History: Debates on Chinese Social History, 1928-1933, Berkeley, University of California Press, 1978, pp. 264-266. 
ruxue revival), Chen Lai and Guo Qiyong (國齊勇) (Wuhan University), aligned themselves unambiguously with the revisionist "explaining antiquity" camp, as I have argued in some detail elsewhere. (23)

As the case of the trend of "explaining antiquity" evidences, a commitment by guoxue's contemporary protagonists to nativist aspirations generally seems to trump any commitment to more cosmopolitan aspirations. As Taiwan-based historian Liu Longxin (劉龍心) points out, the May Fourth generation of "cosmopolitan" guoxue protagonists such as Hu Shi, Gu Jiegang, and Fu Sinian (傅斯年) (1896-1950) "no longer regarded classics, histories, masters, and collected writings as a taxonomy to categorise knowledge but rather regarded them as a source providing the basic historical materials for scholarly research." (24) An attitude similar to Hu Shi's "historical perspective" (歷史的眼光, lishi de yanguang) - which amounted to treating all historical materials equally and not privileging the classics or material derived from elite culture over material derived from folk culture - is rarely in evidence amongst guoxue's contemporary protagonists. The focus remains very much on texts produced and consumed by elite culture. ${ }^{(25)}$

A second observation, again relating to Chen Lai's claim that guoxue was transformed from a political concept in the first period into an academic concept in the third period, is that recently there has been a concerted effort by Chinese academics once again to treat guoxue as a discipline. (26) In particular, a number of proposals have been put forward arguing that guoxue should be accepted as a Level I Discipline Category (一級 學科, yiji xueke) in the tertiary education academic disciplines classification system. Currently there are several tens of Level I Disciplinary Categories. In turn, these are subsumed under 12 broad Disciplinary Fields (學科門類, xueke menlei). (For example, the Disciplinary Field of Economics consists of two Level 1 Disciplinary Categories: Theoretical Economics and Applied Economics). In turn, subsumed under each Level 1 Disciplinary Category are several Specialisations (專業, zhuanye) or Level 2 Disciplinary Categories (二級學科, erji xueke). (For example, Theoretical Economics consists of the following specialisations: political economy, history of economic thought, history of economics, Western economics, world economy, and population, resource, and environmental economics.) $\mathrm{PhD}$ and Masters degree programs correspond to the Level 2 Disciplinary Categories. Thus a given university might offer a PhD program in Western economics but not necessarily in world economy; another university may offer both. If, however, a university is granted the authority to establish a $\mathrm{PhD}$ and Masters program at the Level 1 Disciplinary Category, it is then able to offer PhD and Masters degrees for the full suite of associated Level 2 Disciplinary Categories.

Over the past year or so, a growing chorus of voices has demanded that guoxue be granted Level 1 status. In a recent proposal to establish guoxue as a Level 1 Disciplinary Category, Jiao Guocheng (焦國成) (Renmin University) also specified eight guoxue-related subjects to be established as Level 2 Disciplinary Categories: classical studies, masters studies, evidential studies, institutional studies, material culture studies, technical and divinatory studies, comparative guoxue and Western Studies. (27) Guo Qiyong has gone further. He wants to see guoxue recognised not just as a Level 1 Disciplinary Category but as a Disciplinary Field under which are subsumed five Level 1 Disciplinary Categories: classics, history, masters, collected writings, and Chinese religion. He argues: "If guoxue were established as a Disciplinary Field and classical studies were established as a Level 1 Disciplinary Category, then under classical studies there could be
Level 2 Disciplinary Categories of individual classics (Odes, Documents, Change, Spring and Autumn Annals, the Four Books and so on), of the classics collectively, of the history of the classics, of Old Text and New Text scholarship....The situation for the other disciplines [of history, masters, collected writings, and Chinese religion] can be inferred on this basis." (28)

This is probably more strategic in purpose than it is a genuine proposal. Wuhan University has been at the forefront of pushing for guoxue to be recognised as a Level 1 Disciplinary Category. In 2001 the Philosophy Department established a guoxue experimental class for undergraduates. In 2005 this was expanded into a Masters program and in 2007 it established a PhD and Masters program with guoxue as a de facto Level 1 Disciplinary Category. Because guoxue has not yet been granted Level 1 or Level 2 Disciplinary Category status by the Ministry of Education, the named degree conferred on graduates still needs to be chosen from the Literature, History, or Philosophy programs. (Students are able to choose which one. ${ }^{(29)}$ ) This year, 2010, Wuhan University established a Guoxue Institute with Guo Qiyong appointed as Director.

A third observation relating to Chen Lai's claim that guoxue was transformed into an academic concept in the third period is that this current effort by academics to treat guoxue as a discipline is mired in a long-standing identity crisis, because guoxue in the early twentieth century was no less a product of the disciplinarisation and professionalisation of knowledge that began in Europe and America the previous century, and which was marked by "the creation of permanent institutional structures designed both to produce new knowledge and to reproduce the producers of knowledge." (30) Gan Chunsong (Renmin University), for example, relates that scholars associated with the National Essence movement "planned to establish a National Essence Academy to offer a three-year course that included such subjects as classical studies, philology, ethics, Neo-Confucian moral philosophy, philosophy, religion, politics and law, economics, sociology, history, institutions, archaeology, geography, calendar and mathematics, natural history, essay writing, music, drawing, calligraphy, translation, and so on.... Although everything that was to be studied came from the resources of traditional Chinese learning, this obviously was already an attempt to draw

23. John Makeham, Lost Soul, Chapter 10, "From Doubting Antiquity to Explaining Antiquity: Reconstructing Early Ru Intellectual History in Contemporary China."

24. Liu Longxin, Scholarship and institutions: The disciplinary system and establishment of modern Chinese historiography (Xueshu yu zhidu: Xueke tizhi yu xiandai Zhongguo shixue de jianli), Taipei, Yuanliu chuban gongsi, 2002, p. 163.

25. Occasional gestures are made to include the cultural products of the "singing and dancing minorities" within the ambit of guoxue, but this generally amounts to little more than perfunctory tokenism.

26. Fang Litian (方立天) has even formulated a syllogism to support this view: "Guoxue refers to the scholarship of a country. Scholarship is systematic and specialised learning. Guoxue is thus systematic and specialised learning." Fang Litian, "Guoxue's soul: The Chinese humanist spirit" (Guoxue zhi hun: Zhonghua renwen jingshen), in Zhongguo Renmin daxue Guoxue yuan (ed.), Guoxue forum (Guoxue luntan, First Collection), Beijing, Zhongguo Renmin daxue Guoxue yuan, 2008, p. 58. There are, however, dissenting voices, such as those of Cong Pengcheng (龔䐉程), who denies that guoxue is a speciality or even a subject, describing it instead as the soil in which various types of learning are cultivated. Gong Pengcheng, An introduction to Guoxue (Guoxue rumen), Beijing, Peking University Press, 2008, preface p. 5.

27. Jiao Guocheng, "On the need to add guoxue to the Level 1 Disciplinary Categories" (Zengshe guoxue wei yiji xueke hen you biyao), Guangming ribao, 13 September 2010.

28. Guo Qiyong, "A new discussion on establishing the discipline of guoxue" (Xin shi tan guoxue xueke de shezhi), Guangming ribao, 24 August, 2010

29. The same situation applies at Renmin University where the first cohort of its six-year combined undergraduate-Masters (enrolled in 2005) has recently graduated.

30. Immanuel Wallerstein et al., Open the Social Sciences: Report of the Gulbenkian Commission on the Restructuring of the Social Sciences, Stanford, Stanford University Press, 1996, p. 7. 
on the system of Western disciplines as a model to create new classifications." (31) Liang Tao (梁濤) (Renmin University) similarly notes: "The guoxue research institutions established after the May Fourth period such as Peking University's Guoxuemen, Tsinghua University's Guoxue yanjiuyuan, Yenching University's Guoxue yanjiusuo and so forth, had all essentially modelled themselves after Western disciplines to classify Chinese scholarship and culture, generally dividing it into literature, history, and philosophy, and adding linguistics, philology, archaeology, and so forth." (32)

This situation has prompted others, such as Chen Ming (陳明) (Beijing Normal University), to express concern that because classical studies has been reduced to philosophy, philology, history, or anthropology this leads to methodological confusion and impedes understanding. ${ }^{(33)}$ Others, like jiao Guocheng, despair that: "The Western system of academic disciplines has led to a breaking up and fragmentation of guoxue (or China's traditional learning). Because of this, guoxue cannot exist and develop as an organic whole. Consequently it is difficult to guarantee that China's traditional learning and culture can exert a strong influence among the national cultures of the world." (34) Zhu Hanmin (朱漢民) (Yuelu Academy, Hunan University) similarly complains that the traditional categories of learning associated with the Four Divisions (classics, history, masters, and collected writings) have not only each been subjected to dislocation but that the knowledge contained in each has become mere "material" for disciplines introduced from the West. ${ }^{(35)}$ These views often go hand in hand with such claims as that the difference between Western schemes of knowledge classification and Chinese approaches to learning is analogous to the differences between the holistic approach of the practitioner of traditional Chinese medicine and the analytic approach of the practitioner of Western medicine. (36) The conundrum for contemporary guoxue protagonists is that the stronger the claim made that guoxue warrants disciplinary status (and hence taxonomic division), the weaker the case that guoxue is a holistic field of learning.

\section{The ethnoepistemological trend}

Over the last two decades or so there has been a growing movement in Taiwan and Hong Kong to "Sinicise" or "indigenise" the social sciences, in particular social psychology, anthropology, and sociology. (37) The movement promotes a return to the cultural roots of "being Chinese" and the development of "Sinicised" social and behavioural science approaches to research. This has been in response to the perceived threat that universalist claims of theory pose to the particularity of local cultural identity. (38)

Over the past decade, a growing number of Chinese academics have similarly argued that "Western philosophy" has yet to acknowledge "the legitimacy" of Chinese philosophy and to engage it as an equal partner in dialogue. They have further insisted that the articulation and development of China's philosophical heritage must draw principally on the endogenous paradigms and norms of China's indigenous heritage, and that paradigms and norms derived from the West, in particular, are not only inappropriate but fundamentally hegemonic and/or ill suited to China's "conditions." Discussion of these and related issues reached a watershed with the publication of two influential essays - one at the end of 2001 and one early in 2002 - by two prominent Chinese scholars of Chinese philosophy. ${ }^{\left({ }^{39}\right)}$ These essays marked the beginning of a period of debate and discussion focused on the topic of "the legitimacy of Chinese philosophy."
A few examples of this discussion ${ }^{(40)}$ will serve to illustrate typical concerns. In the very opening passage of the first volume of his famous Zhongguo zhexueshi (中國哲學史, A History of Chinese Philosophy; 1934), Feng Youlan (1895-1990) proclaimed that one of the main tasks in writing a history of Chinese philosophy is as follows: "From all the various types of learning in Chinese history, select and provide a narrative account of those aspects that can be named according to what is called philosophy in the West." (41) Writing in 2003, Zhang Liwen (Renmin University), provided the following critique of Feng's proposal:

Such a narrative account would inevitably lead to the dismemberment of the various forms of traditional Chinese learning, that is, to the disintegration and smashing into pieces of China's various branches of learning that together constitute an organic whole, by picking out "those aspects that can be named according to what is called philosophy in the West," discarding those aspects that cannot, and then reassembling [what is left]. The outcome of such a reassembly would... bring to an end the living existence of Chinese learning, thought, or philosophy. It would be just like in Zhuangzi where, in order to repay Hundun for his kind hospitality, Shu and Hu chiselled seven holes in Hundun [so he would be] just like them, but when the seven holes were completed Hundun died. (42)

In a similar vein, Chen Shaoming (陳少明) (Zhongshan University) wrote:

In many textbook-style writings, once traditional thought has been subjected to the analytical framework of Western philosophy, the inherent integrity of the meaning of traditional thought becomes

31. Gan Chunsong, "Guoxue: Identifying with the nation-state and reflecting on disciplines ("Guoxue": Guojia rentong and xueke fansi), Zhongguo shehui kexue, no. 3, 2009, pp. 57-58.

32. Liang Tao cited in "Guoxue is a discipline" (Guoxue shi yimen xueke), Guangming ribao, 12 October 2009 .

33. Chen Ming, "Expectations and doubts: Looking at Renmin University's Guoxue Institute from the perspective of the Tsinghua Guoxue Research Institute" (Qidai yu yilü: Cong Qinghua Guoxue yuan kan Renda Guoxue yuan), in his Cultural ruxue: Thoughts and arguments (Wenhua ruxue: sibian yu lunbian), Chengdu, Sichuan renmin chubanshe, 2009, p. 178.

34. Jiao Guocheng, "On the need to add guoxue to the Level 1 Disciplinary Categories," art. cit.

35. Zhu Hanmin cited in "Guoxue is a discipline."

36. Gong Pengcheng, An introduction to guoxue, op. cit., p. 11.

37. Maukuei Chang, "The Movement to Indigenize the Social Sciences in Taiwan: Origin and Predicaments" in John Makeham and A-chin Hsiau (eds.), Cultural, Ethnic, and Political Nationalism in Contemporary Taiwan: Bentuhua, New York, Palgrave Macmillan, 2005.

38. As Arif Dirlik notes in his essay in this issue of the journal, "Epistemological nativism, or a general valorization of ethnoepistemology, is a pervasive (if not defining) characteristic of contemporary global modernity."

39. The two essays are Zheng Jiadong, "The problem of the 'legitimacy' of 'Chinese' philosophy" ("Zhongguo" zhexue de "hefaxing wenti") in Chinese Philosophy Institute, Chinese Academy of Social Sciences (ed.), Zhongguo zhexue nianjian 2001, Beijing, Zhexue yanjiu zazhishe, 2001; and Chen Lai (陳來), "The challenges facing the study of Chinese philosophy" (Zhongguo zhexue yanjiu de tiaozhan), Zhongguo shehui kexue wenzhai, no. 2, 2002.

40. For an analysis of the discussion see Carine Defoort, "Is There Such a Thing as Chinese Philosophy? Arguments of an Implicit Debate," Philosophy East and West, vol. 51, no. 3, July 2001, pp. 393-413; "Is 'Chinese Philosophy' a Proper Name. A Response to Rein Raud," Philosophy East and West, vol. 56, no. 4, 2006, pp. 625-660. Three issues of Contemporary Chinese Thought (vol. 37, no. 1, 2005 - vol. 37, no. $3,2006)$ are devoted to translations of representative articles on the topic of the legitimacy of Chinese philosophy.

41. Feng Youlan, A history of Chinese philosophy (Zhongguo zhexueshi), Shanghai, Shangwu yinshuguan, vol. 1, 1934, p. 1.

42. Zhang Liwen, "Chinese philosophy's self account and account of itself: Finding a way out of the crisis of Chinese philosophy and overcoming the problem of legitimacy" (Zhongguo zhexue de "ziji jiang," "Jiang ziji": lunzouchu Zhongguo zhexue de weiji he chaoyue hefaxing de wenti), Zhongguo renmin daxue xuebao, vol. 2, 2003, p. 3. 
dislocated and completely unrecognisable. In this way, there is a total disconnect between the feeling one gets from reading the canonical writings and from reading textbook interpretations.... In these formulaic narratives of the histories of philosophy [found in textbooks] Chinese concepts are often used to draw far-fetched analogies with Western philosophical categories, and Chinese classics are imperceptibly transformed into examples illustrating [principles of] Western philosophy. ${ }^{(43)}$

Jing Haifeng (景海峰) (Shenzhen University) has been one of the most trenchant critics of Chinese attempts to ape Western models of philosophy. For Jing, the institutionalisation of philosophy as an academic discipline has meant that so-called Chinese philosophy has effectively become little other than Western-style philosophy with a Chinese mask. He complained that despite the developments over the past century in the study of Chinese philosophy, as well as the professionalisation and institutionalisation of the discipline, the actual content of Chinese philosophy remains insubstantial and devoid of real content. ${ }^{(44)}$

Continuing in this vein, Wei Changbao insists that the study and development of Chinese philosophy must not be guided by the paradigms of "Western philosophy" but rather by endogenous theoretical discourses. "We must endeavour to return to Chinese philosophy's own theoretical contexts and problematics so as to establish the subjectivity or self-determination of Chinese philosophy and to promote the indigenisation (本土化, bentuhua) ... of Chinese philosophy." (45)

In addition to this trend towards so-called indigenisation, a closely related concern has been that Chinese thought and scholarship should occupy a position as benchmark or standard when conducting research into Chinese philosophy. Wang Zhongjiang (Chinese Academy of Social Sciences) provides the following overview:

Corresponding to the strengthening of people's identification with Chinese history and tradition since the 1990s, everyone has been deeply disturbed by the adverse effects caused by the use of Western paradigms to explain Chinese learning. As people began to entertain doubts about the customary method of using Western philosophical paradigms and concepts to investigate Chinese philosophy, some people began to waver even about the term "Chinese philosophy," which has long been in currency as a representative aspect of "Chinese learning"... "Simplistic, forced analogies" and "misreading" may merely be problems of detail, but concealing or sacrificing Chinese philosophy's intrinsic "problematic," "ways of thinking," and "inner structures and goals" causes systemic harm. This is at least part of the reason for the sympathetic and welcoming reception in China of [Paul A.] Cohen's "China-centred perspective" and [Edward] Said's "Orientalism." This is also a background factor for why some of us have called out for the "indigenisation" of Chinese scholarship, or for returning to a Chinese linguistic context or even using classical Chinese to speak. ${ }^{(46)}$

Although the intensity of the "legitimacy of Chinese philosophy" discussions eased from about 2005, guoxue has become a natural host for these same concerns, as the following comments by Li Jinglin (李景林) and Xu Jiahuang (Beijing Normal University) clearly show:
As early as the 1980s there were already scholars who had expressed reservations about the level of applicability of social science norms formulated on the basis of Western historical experiences. At the turn of this new century, the surge in retrospective and prospective scholarly activities relating to a century of humanities disciplines [in China] also strongly advanced self-awareness of Chinese academic methodology. Discussion in recent years of such issues as historiographical method, ruxue religiosity, and the legitimacy of Chinese philosophy are also an expression of this. An emphasis that research on Chinese scholarship and thought should form its own unique methods of expression, research, and interpretation has already became a powerful voice in the Chinese academic world. Recently, "guoxue fever" has arisen in response to this trend. Now, those people who place their hopes in guoxue are using it to rebuild the character and uniqueness of Chinese scholarship and culture, maintaining that the revitalisation of Chinese culture is to lay the foundation for [China's] scholarship and spirit. (47)

That this is true even for the most influential proponents of guoxue is confirmed in the following recent comments by Chen Lai (who like other prominent figures in the promotion of guoxue was also a leading protagonist in the "legitimacy of Chinese philosophy" discussions):

\section{Another function of guoxue is that it helps to get rid of "Western} culture-centrism" and the attendant influence that its cultural hegemony has on us.... Historians have long pointed out that China's several thousand years of continuous recorded history is unique in the world. The principles informing all social sciences must both undergo and pass the validation of China's historical experience; only then can their veracity be proven. "Guoxue fever" helps people reflect upon Western culture's adopting the position that the particular is the universal; to reflect upon the importation or transplantation of Western academic systems; and by means of Chinese experience and Chinese wisdom establish Chinese cultural subjectivity so as to promote equality of interaction in a multicultural world. ${ }^{(48)}$

One might well be surprised by the pronounced nationalistic tone of these remarks, given some of Chen's other remarks cited above about "close liaison with international research on Chinese culture." The strong cultural nationalism also seems difficult to reconcile with the fact that the Tsinghua Guoxue Research Institute (officially translated as "The Academy of Chinese Learning") has established a Liang Qichao Memorial Visiting Professorship to give the Liang Qichao Memorial Lectures. It is mooted

43. Chen Shaoming, "Once more on the appropriateness of 'Chinese philosophy' " (Chongti "Zhongguo zhexue" de zhengdangxing"), Jiang-Han Luntan, no. 7, 2003, p. 34.

44. Jing Haifeng, "A modern interpretation of Chinese philosophy" (Zhongguo zhexue de xiandai quanshi), Beijing, Renmin chubanshe, 2004, pp. 210, 241-247 passim.

45. Wei Changbao, "The narrative of Chinese philosophy's 'legitimacy' and how to overcome it" (Zhongguo zhexue de "hefaxing" xushi ji qi chaoyue), Zhexue Dongtai, no. 6, 2004, pp. 7-9, passim.

46. Wang Zhongjang (王中江), "Paradigms, profound perspectives and research models for Chinese philosophy" ("Fanshi," "shendu guandian" yu Zhongguo zhexue "yanjiu dianfan"), Jiang-Han luntan, no. 7, 2003, pp. 26, 27.

47. Li Jinglin and Xu Jiaxing (許家星), "Guoxue: The garden of Chinese academic culture" (Guoxue: Zhongguo xueshu wenhua de jiayuan), in Tang jin (ed.), Strategies for a big country: Guoxue fever and cultural transmission (Da guo ce: guoxue re yu wenhua chuancheng), Beijing, Renmin ribao, 2009.

48. Chen Lai, "How should guoxue fever be regarded?", art. cit. 
that the first four Visiting Professors are likely to be Western scholars rather than Chinese scholars. ${ }^{(49)}$ One of the characteristics of the so-called New Guoxue is that in addition to aspiring to an international academic standing, its supporters want to be seen as opposed to any suggestion of scholarly insularity and cultural chauvinism. ${ }^{(50)}$ Despite this, the issues I have described above will continue to occupy the energies and concerns of many Chinese intellectuals and, in the short term at least, contribute to guoxue's continued growth. This is because they feed directly into longstanding, pervasive, and deep-seated concerns about the threat to Chinese cultural identity posed by subjugation to the cultural assumptions built into theories formulated under Western cultural circumstances. ${ }^{(51)}$

49. Four is the number of the original Tsinghua Guoxue Institute's Four Great Mentors (si da daoshi): Liang Qichao, Wang Guowei, Chen Yinke, and Zhao Yuanren. Arif Dirlik is the inaugural Liang Qichao Memorial Visiting Professor.

50. There may also be another influence at work here, in the case of Chen Lai at least. Chen's teacher, Zhang Dainian (1909-2004), continues to be influential because of the dialectical methodology he is credited with developing, called "critical inheritance (pipan jicheng) and synthetic creation (zonghe chuangxin)." Although Zhang had already advanced the concept of synthetic creation in the 1930s, it was during the "culture fever" of the 1980s that he actively promoted the concept in many of his writings and lectures: "On the one hand, we must conscientiously summarise and reflect upon our nation's traditional culture, and form a clear recognition of its dross and essence; on the other hand, we must make a penetrating study of Western culture, analyse it concretely, and clearly discern its strengths and weaknesses. Then, on the basis of critically inheriting and transmitting traditional Chinese culture and critically drawing on modern (jindai) Western culture, we must synthesise the two to create socialism's new Chinese culture. This culture will be both new and Chinese. I call this point of view "synthetic creation." (Zhang Dainian, "A letter on New Confucian studies" (Guanyu ruxue yanjiu de xin), Zhexue yanjiu, no. 6, 1990, p. 110). His most detailed account of synthetic creation is set out in a book co-written with his student, Cheng Yishan, Chinese culture and culture debate (Zhongguo wenhua yu wenhua lunzheng), Beijing, Zhongguo renmin daxue chubanshe, 1990. See in particular the last chapter.

51. On a far more speculative note, the idle philosopher might wonder if another "deep structural" factor underpinning the ethnoepistemological dimension of guoxue is what Thomas Metzger has referred to as "epistemological optimism." Metzger identifies an "epistemological optimism" common to Chinese Marxism, Sunism, modern Confucian humanism, and Chinese liberalism. At the heart of this optimism he finds the metaphysical claim that humans can use intuition or dialectical reasoning to attain knowledge of, or even become one with, an ineffable ultimate reality that governs the natural world, history, and ethical life. Might this optimism in some way also account for the self-assuredness (and assertiveness) of modern Chinese ethnoepistemological positioning? Metzger traces the ideological grounding of this epistemological optimism to "the Confucian and Neo-Confucian tradition." Thomas Metzger, $A$ Cloud across the Pacific: Essays on the Clash between Chinese and Western Political Theories Today, Hong Kong, Chinese University Press, 2005, p. 673. 